\title{
Antibacterial effects of essence of Bene tree fruit on Clostridium perfringens in laboratory environment and on meat product
}

\author{
Soltan Dallal MM ${ }^{1}$, Faraji $\mathbf{M}^{2}$, Mirahmadi $\mathbf{F}^{3}$ \\ 1. Professor of Microbiology, Food Microbiology Research Center/ Division of Microbiology, Department of Pathobiology, \\ School of Public Health, Tehran University of Medical Sciences, Tehran, Iran, (Corresponding Author) Tel: +98-21- \\ 88992971, Email: msoltandallal@gmail.com \\ 2. MSc Student of Food Microbiology, Devision of Food Microbiology, Department of Pathobiology, School of Public \\ Health, Tehran University of Medical Sciences, Tehran, Iran.
}

3. Instructor, Department of Food Industrial, Azad University, Branch of Sanandaj, Sanandaj, Iran

\begin{abstract}
Background and Aim: Essence of $P$. atlantica Subsp. Kurdica fruit or wild pistachios have been recognized as an anti- microbial compound against most of microorganisms. The purpose of this study was to determine the anti-microbial activity of the essence of $P$. atlantica Subsp. Kurdica fruit on Clostridium perfringens in laboratory environment and meat products.
\end{abstract}

Material and Method: The anti-microbial effects of the essence of $P$. atlantica Subsp. Kurdica fruit on Clostridium perfringens was evaluated by determination of minimum inhibitory concentration (MIC) and minimum bactericidal concentration (MBC). Then MBC of the essence was added to the processed foods (hot dog and kielbasa) in order to reduce anaerobic microbes especially Clostridium. Using SAS software, data were analyzed by chisquare test. $\mathrm{p}<0 / 05$ was considered significant.

Results: The results showed that MIC for Clostridium bacteria was 250 milligrams per liter. MBC of $P$. atlantica Subsp. Kurdica essence for Clostridium bacteria was 500 milligrams per liter. Use of 500 milligrams per liter of $P$. atlantica Subsp. Kurdica essence in the food products such as hot dogs had bactericidal effect on Clostridium bacteria.

Conclusions: The essence of $P$. atlantica Subsp. Kurdica in the food product such as hot dogs had inhibitory and anti-bacterial effects on Clostridium. This essence had no positive effect on the taste of food product. This problem can be solved by purification and decolorization. It can be used as a drug or remedy for the treatment of Clostridium infection or poisoning.

Keywords: $P$. atlantica Subsp. Kurdica fruit essence, Clostridium perfringens, Minimum inhibitory concentration (MIC), Hot dogs and sausages, Organoleptic properties

Recevied: Sep 17, 2018

Accepted: Feb 20, 2019

How to cite the article: Soltan Dallal MM, Faraji M, Mirahmadi F. Antibacterial effects of essence of Bene tree fruit on Clostridium perfringens in laboratory environment and on meat product. SJKU 2019; 24 (1): 112-121.

Copyright (C) 2019 the Author (s). Published by Kurdistan University of Medical Sciences. This is an open access article distributed under the terms of the Creative Commons Attribution-Non Commercial License 4.0 (CCBY-NC), where it is permissible to download, share, remix, transform, and buildup the work provided it is properly cited. The work cannot be used commercially without permission from the journal. 


\section{بررسى اثرات ضدباكتريايى اسانس ميوه درخت بنه بر روى باكترى كلستريديوم يرفرنجنس} در محيط آزمايشكاهى و سوسيس

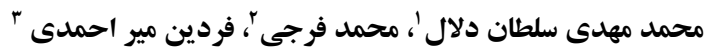

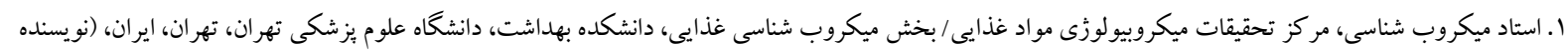

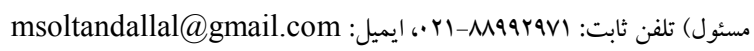

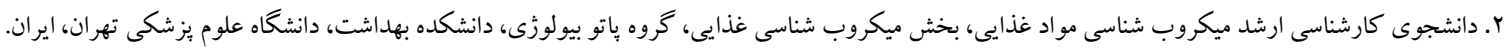

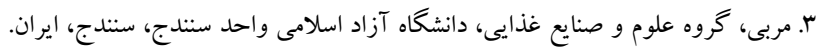
جككيده زمينه وهدف: اسانس ميوه درخت بنه يا پِسته وحشى به عنوان تركيب ضد ميكروبى در مقابل اكثر ميكروار كانيسم ها شناخته

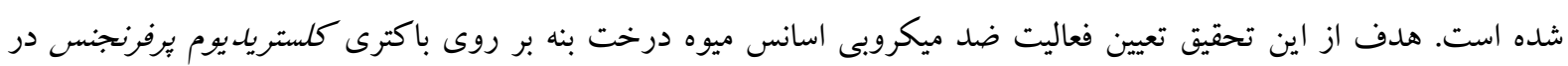
محيط ازمايشكاهى و فراورده هاى گوشتى ميباشد. روش بررسى: در اين تحقيق اثرات ضد ميكروبى اسانس ميوه درخت بنه برروى كلستريديوم برفرنجنس ، به روش تعيين غلظت

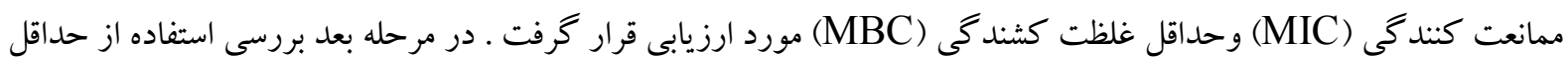

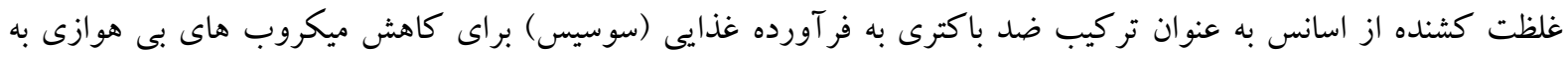
خصوص كلستريديوم انجام شد. براى تجزيه و تحليل داده ها از آزمون كاى اسكوئر و نرم افزار SPSS استفاده شده و موارد

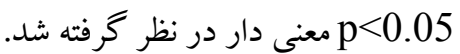

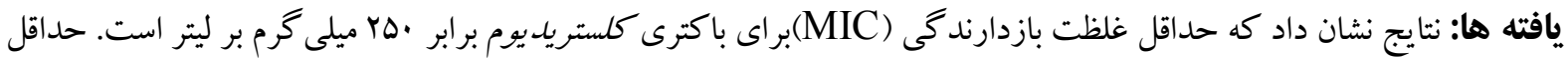

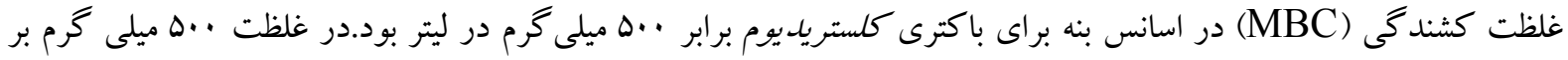

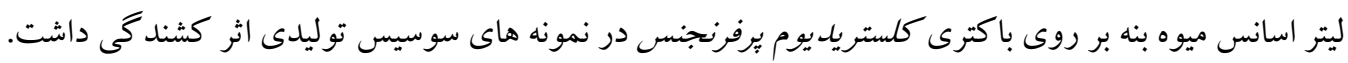

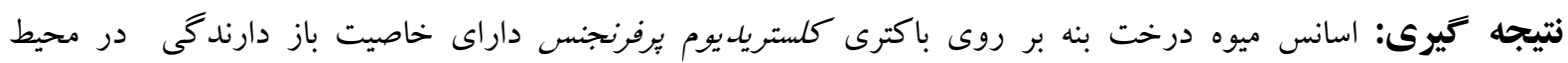

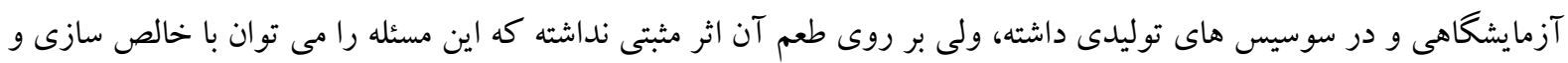

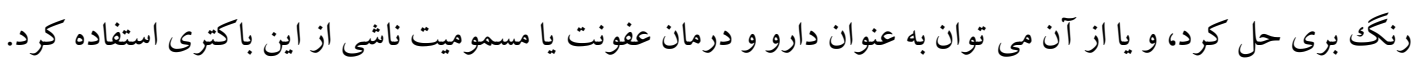

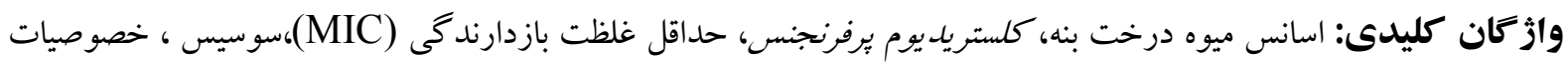
اركانوليتيك وصول مقاله :9V/9/T9 اصلاحيه نهايى:9V/9/Y9 يذيرش:9V/TY/T 
كردستان مطرح مى باشد(F). نتايج بررسى ها نشان مى دهد

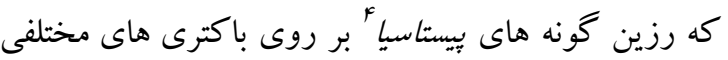

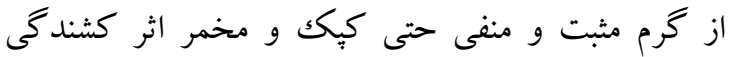

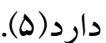

اكر جه داروهاى شيميايى بهطور سريع اثر بخشند، ولى اكثر آنها عوارض جانبى نامطلوبى بر بدن انسان بر جاى

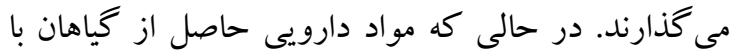
آن كه به تدريج تأثير گذار مى باشند، داراى اثرات مونى مفيدى

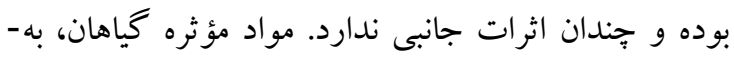
خصوص عطريات و اسانسها، موارد استفاده متعدد و و مؤره متفاوتى در صنايع لوازم آرايش، صنايع مواد شيميايى

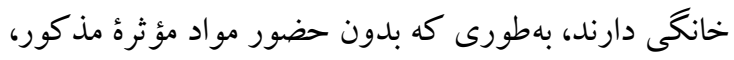

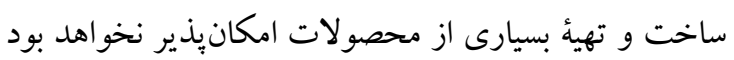

در حال حاضر در ايران بيش از يـنج هـزار واحـد عطـارى

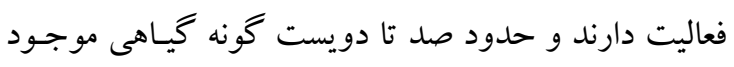

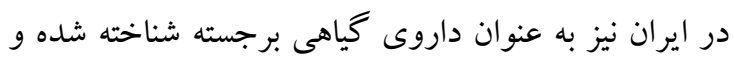

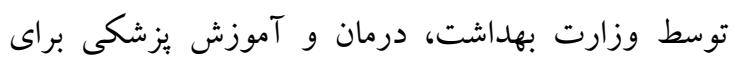

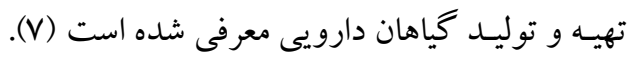

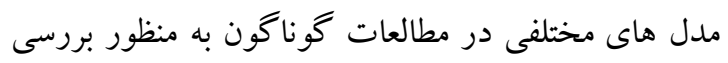

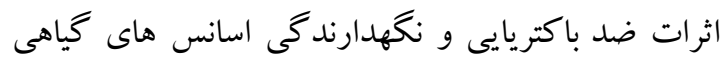
استفاده شده است .در برخى از اين روش ها از مدل هاى

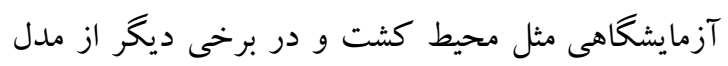
هاى غذايى براى بررسى اثرات ضد باكتريايى اسانس ها

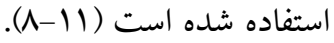
در واقع قرنها است كه مواد موثره استخراج شده از گياهان و ادويه ها توسط مصريان باستان و كشورهاى آسيايى مانند جين و هند استفاده مى شوند، اما در طول سالهاى اخير كاربردهاى دارويى اين تركيبات نسبت به ايجاد طعم و بو

\footnotetext{
${ }^{4}$ Pistacia
}

كياهان دارويى' به گياهانى گفته مىشود كه داراى مواد

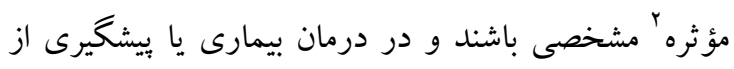
بروز آن در انسان يا دام مورد استفاده قرار گيرند و هم جنينين

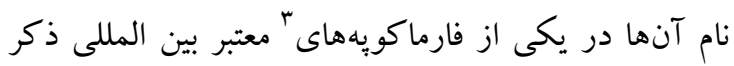

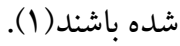
از زمانهاى قديم تاكنون گياهان دارويى به دليل داشتن اسانس، نقش مهمى در سلامتى انسان داشته اند. گياهان

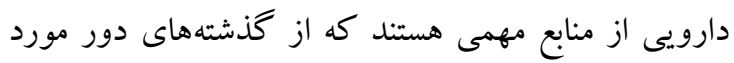

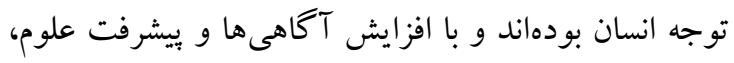
اطلاعات وييرامون گياهان دارويى افزايش يافته است.

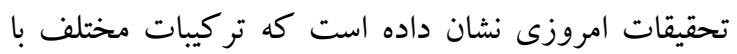
اثرات متفاوتى در گياهان وجود دارد و در اكثر موارد اثرات

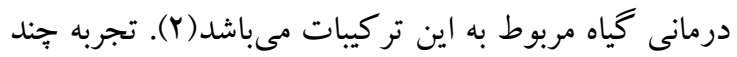

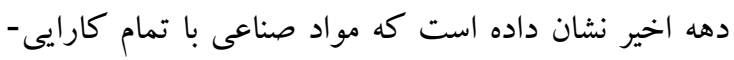
هاى مورد توجه، اثرات نامطلوب و ناخو استه بسيارى به به بهاب همراه دارند و بههمين دليل توجه محققان به تحقيقات و و آزمايشات بر روى گياهان براى جايگزين كردن دون آنها

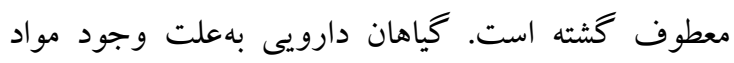
مؤثره طبيعى و همراه بودن اين مواد مؤثره با مواد ديخر

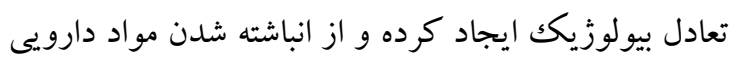
در بدن جلو گيرى مى كنند. عوارض جانبى كم و يا فقدان عوارض جانبى داروهاى با منشاء گياهى در دهههاى اخير، توجه جهانيان و محققان به اين داروها را به خود جلب كرده بانيا

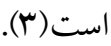
درخت بنه به عنوان منبع توليد رزين (صمغ) يكى ازخونه هاى رستنى در سلسله جبال زاكرس و و بويزه استان

\footnotetext{
1 Medicinal plants

2 Active substances

3 Pharmacopoeia
} 
محيط كشت رين فورست كلستريديوم براث كرم از بودر اين محيط كشت رادر ..1 ميلى ليتر آب

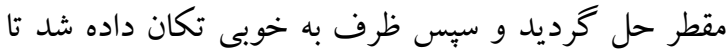
زمانى كه يودر به طور كامل حل گرديد. سبس سر ارلن را

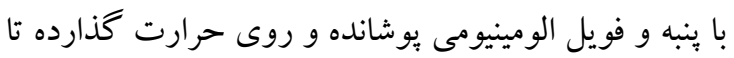
بجوشد و كاملا يكك نواخت شود. سبس محلول اتو كلاو

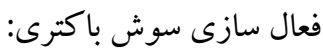

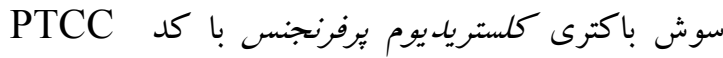

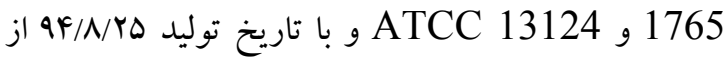
مركز منطقه اى كلكسيون قارج ها و باكترى هاى صنعتى

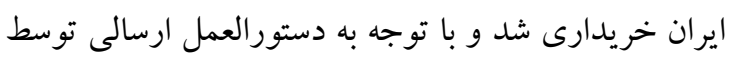
خود سازمان تامين كننده سوش باكترى در محيط كشت تعيين شده توسط سازمان (RCB شد. بدين صورت كه ابتدا آميول حاوى ميكروار گانيسم

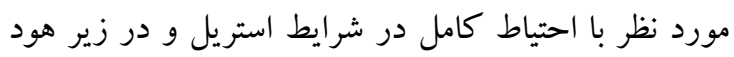
لامينار فلو شكسته شد. سيس با استفاده از سميلر حدود نيم

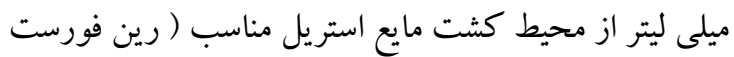

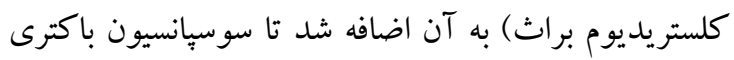
حاصل شود. سبس بخش اعظم سوسيانسيون حاصل شده از باكترى، به محيط كشت رين فورست كلستريديوم براث

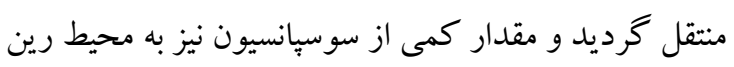
فورست كلستريديوم آكار كه توسط سازمان بثزوهش هاى علمى و صنعتى ايران در مورد اين سويه بيشنهاد شده بود،

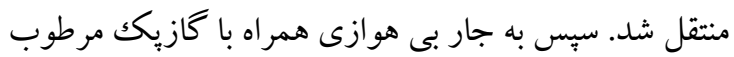

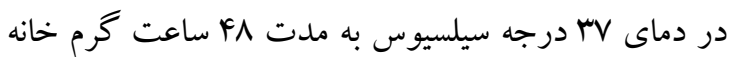

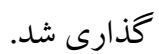
از كلنى هاى تشكيل شده با روش هاى كشت خطى و با بكار گيرى محيط كشت اختصاصى كشت تهيه گرديد و

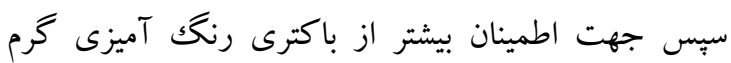

${ }^{7}$ Reinforced Clostridial Broth(RCB)
توسط آنها در درجه دوم اهميت قرار گرفته است، با اين وجود در حال حاضر همجنان در هند برخى از ادويه ها ماند ميخك،، دارجين، خردل، سير، زنجبيل و نعنا به عنوان نسخه هاى سلامتى استفاده مى شوند (YI). با توجه به عدم

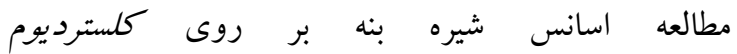

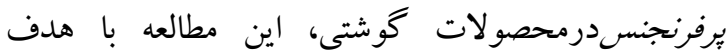
بررسى اثرات ضدباكتريايى اسانس ميوه درخت بنه بر روى باكترى كلستريديوم برفرنجنس هدر محيط آزمايشكاهى و سوسيس انجام شده است.

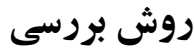
اين مطالعه از نوع تجربى و آزمايشگاهى وبراى تعيين خاصيت ضد باكتريايى اسانس ميوه درخت بنه از روش filter paper disc diffusion Method قطر هاله رشد وبراى تعيين فاكتور MIC و MBC از روش Liquid broth cultureاستفاده گرديد. جمع آورى وخشك كردن گياه: ابتدا ميوه درخت از ارتفاعات كردستان درماه ارديبهشت

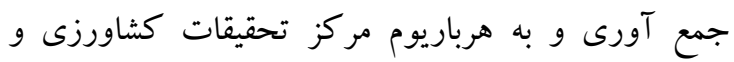
منابع طبيعى استان كردستان انتقال داده شدند، تا از نظر كياه شناسى تاييد شوند.سيس نمونهاى به روش خشك كردن

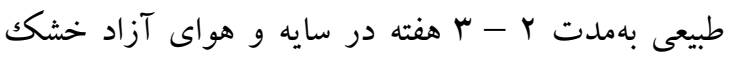
شدند.

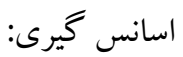
اسانس گيرى با استفاده از روش تقطير با آب و با استفاده از دستكاه كلونجر (British Pharmacopea) انجام شد. محيط هاى كشت آماده سازى محيط كثت برطبق دستورالعمل تجارى نوشته شده بر روى بسته صورت گرفت. به عنوان مثال جهت تهيه

\section{${ }^{5}$ Clostridium perfringens}

${ }^{6}$ Hydrodistillation 
114 براسى اثرات ضد باكتريايی......

كيلو گرم ادويه و مقدارى يخ نيز به گُشت اضافه كرده و

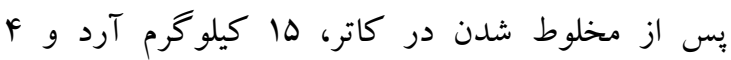
كيلو گرم كلوتن همراه مقدار ديخرى يخ به مخلوط درون كاتر اضافه شد. يس از اينكه خمير درون كاتر به خوبى مخلوط و يكدست شد، ·r كرم يودر اسيد آسكوربيك را در مقدارى كمى آب حل كرده و به امولسيون تشكيل شده در كاتر اضافه شد. امولسيون حاصل خميرى يكك دست و روان بوده و دماى آن در يايان كار حداكثر rا درجه سيلسيوس بود. مخلوط فارش سوسيس دركارخانه بيستون

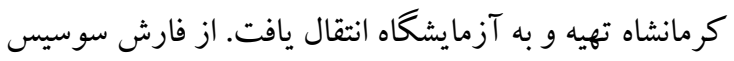
بدون نيترات مقدار . .ب گرم با .س ميلى ليتر سوسيانسيون حاوى كلستريليوم يرفرنجنس باكترى مخلوط و بر روى محيط يليت كانت آكار كشت داده شد. از مخلوط آلوده فوق نيز به منظور كنترل غلظت كلستريديوم برفرنجنس در محيط كشت سولفيت بلى ميكسين سولفاديازين آكار '1 كشت به عمل آمد. در مرحله بعد تحت (SPS agar) شرايط استريل، •ه گرم از مخلوط فارش آلوده، تزريق و به آن PPM 80 نيترات سديم به عنوان شاهد اضافه و به طور كامل مخلوط شد. سيس .q گرم از مخلوط فارش آلوده توزين و به آن ه گرم يودر اسانس بنه اضافه و به طور كامل مخلوط شد. تمامى نمونه ها در اندازه هاى ·ـأكرمى در ظروف مورد نظر بر و به يخجال 4 درجه سيلسيوس انتقال داده شدند. در در دوره هاى زمانى صفر (روز اول انجام كار

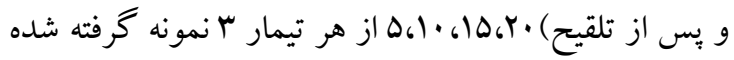

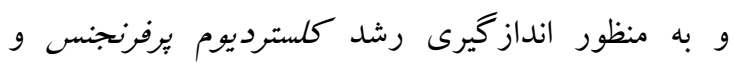
شمارش كلى، محيط كشت سولفيت بيلى ميكسين سولفاديازين آكار و محيط پيليت كانت آكار كشت مخلوط انجام شد، و سيس به مدت FA ساعت و VY ساعت در دماى

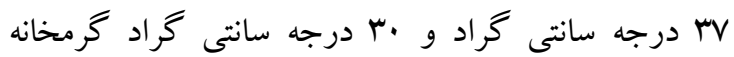
كذارى شدند. به منظور شمارش و شناسايى ميكروار گانيسم از كلنى كانتر مدل FunkeGerbe استفاده شد.

${ }^{10}$ Sulfite Polymyxin Sulfadiazine Agar(SPS agar)
صورت گرفت و در زير ميكروسكوب مورد بررسى قرار كرفت. در نهايت محيط كشت هاى مادر و ذخيره به منظور استفاده هاى بعدى در يخجال نخهارى شدند. تعيين حداقل غلظت مهارى (MIC) و و حداقل غلظت كشند جهت انجام آزمايشات كمى براى تعيين MIC و MBC از اسانس ها رقت هاى مورد استفاده در روش سا لوله اى كه داراى سه لوله كنترل و •الوله رقت اسانس درمحيط مولر هينتون براث و يا محيط براث بيشنهادى توسط مركز كلكسيون قارج و باكترى كه سوش خالص از آنها خريدارى شده بود ، تهيه گرديد. سيس به هر كدام از رقتها به ازاى هرميلى ليتر محيط مايع،CFU/m1 فعال اضافه كرديد. دركنارلوله ها ازكنترل مثبت (محيط كشت حاوى باكترى بدون اسانس) و كنترل منفى (محيط

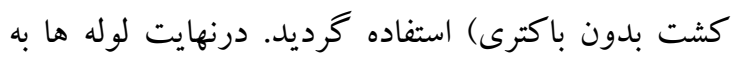
مدت MF ساعت در MV درجه سانتيخر اد انكوبه وسيس نتايج قرائت گرديد. براى هر كدام از اسانس ها آخرين رقتى كه

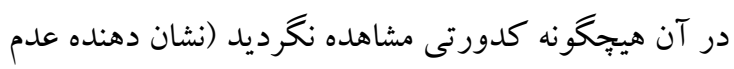

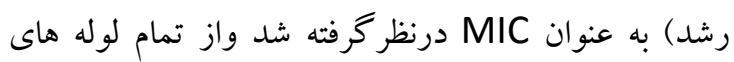
بدون كدورت بر روى محيط مولر - هينتون آكار كشت

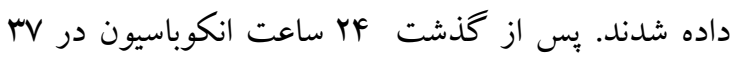
درجه سانتيخر اد آخرين رقتى ازاسانس ها كه قادر به مرگك 99 \% درصدازباكتريهاى زنده اوليه بود به عنوان MBC درنظر گرفته شد(9). روش تهيه فارش سوسيس

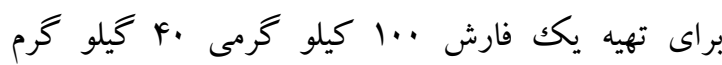
كوشت قرمز جرخ كرده و •ا گرم نيتريت سديم كه در مقدار كمى آب حل شده بود در كاتر مخلوط شد. پِ از آن مقدارى يخ بيولكى به مخلوط درون كاتر اضافه و در

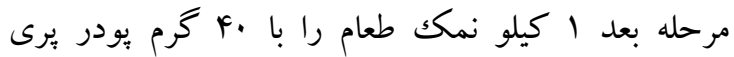
فسفات سديم مخلوط كرده و به گوشت اضافه شد. سيس 1

\footnotetext{
8 Minimal Inhibitory Concentration

${ }^{9}$ Minimal Bactericidal Concentration
} 


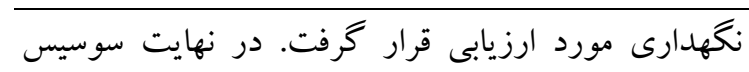

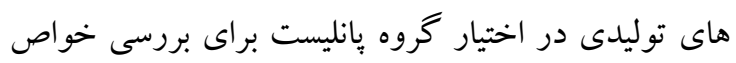
حسى قرارداده شد. نتايج ارزيابى فعاليت ضد ميكروبى اسانس بنه بر باكترى

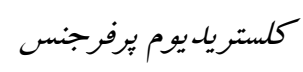
حداقل غلظت مهار كننده رشد (MIC) وحداقل غلظت

$$
\text { كشندگى (MBC) }
$$

نتايج بررسى حداقل غلظت بازدارنده اسانس بنه بر روى

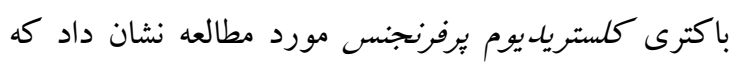

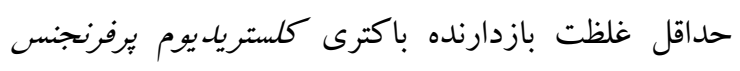
.

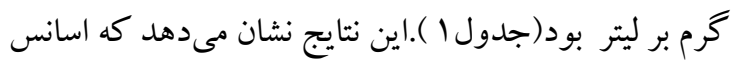

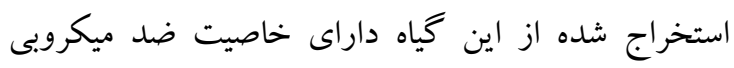

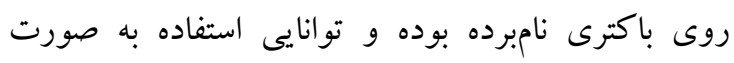

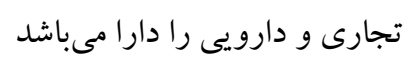

روش تجزيه و تحليل اطلاعات:

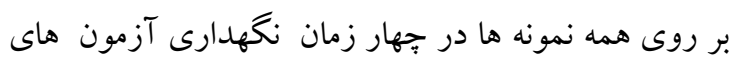

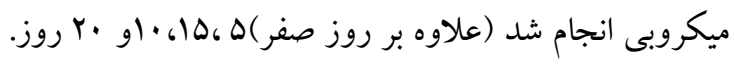
براى تجزيه و تحليل داده ها از آزمون كاى اسكوئر و نرم افزار SPSS استفاده شده و موارد نظر گرفته شد.

يافته ها اين مطالعه در سه مرحله انجام گرفت در مرحله اول اسانس

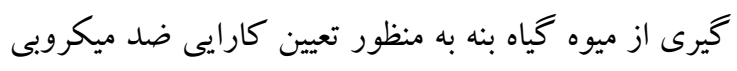

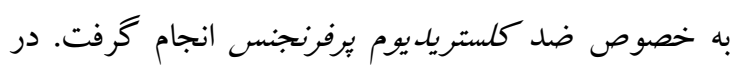
مرحله دوم تعيين حداقل غلظت ممانعت كنند خى (MIC)

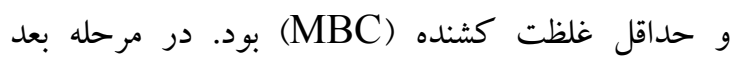
افزودن اسانس ها در غلظت حداقل غلظت كشنده به نمونه

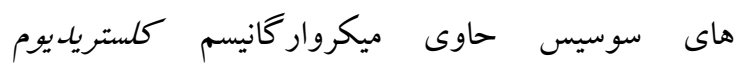
برفرنجنس در غلظت نيم مكك فارلند بدست آمده با روش كائس

\begin{tabular}{|c|c|c|c|}
\hline Tube & ميلى گرم بر ليتر & $\mathrm{MIC}$ & $\mathrm{MBC}$ \\
\hline 1 & 2000 & - & - \\
\hline r & 1000 & - & - \\
\hline$r$ & $\Delta .$. & - & - \\
\hline f & ro. & - & + \\
\hline$\Delta$ & iro & \pm & + \\
\hline 9 & ar.s & + & + \\
\hline v & M.ro & + & + \\
\hline$\wedge$ & 10.950 & + & + \\
\hline 9 & vAlis & + & + \\
\hline 1. & $r .9 .94$ & + & + \\
\hline \multicolumn{2}{|c|}{ كنترل ميكروب } & + & + \\
\hline \multicolumn{2}{|c|}{ كنترل محيط كشت } & - & - \\
\hline \multicolumn{2}{|c|}{ كنترل اسانس ميكروبى } & - & - \\
\hline
\end{tabular}

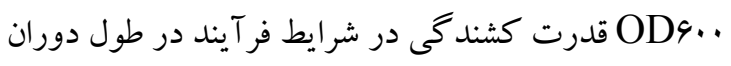

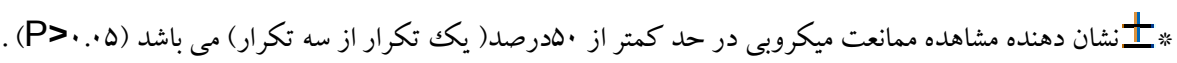


11

براى توليد سوسيس ها به همه نمونه ها بر اساس اثر متقابل تيمارهاى اصلى انواع نمونه و مدت زمان نكهدارى از لحاظ ويز گى لكاريتم تعداد كلستريديوم

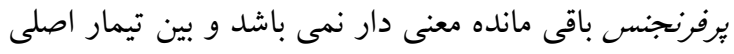

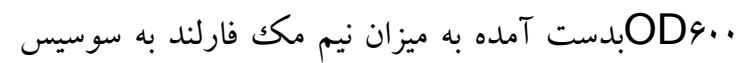

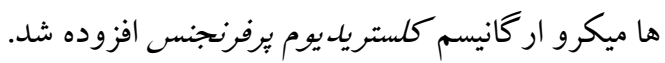

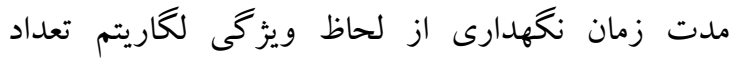

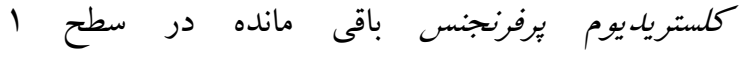
درصد(1...>P) اختلاف معنى دار و وجود دارد.

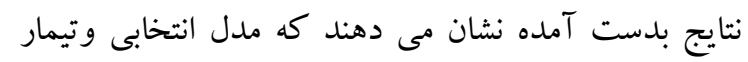

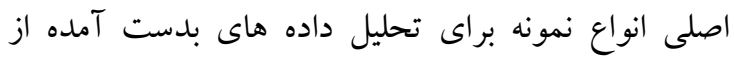
لحاظ ويز گى تعداد كلستريديوم برفرنجنس باقى مانده مورد برد بررسى در سطح هدر صد (ه...>P) معنى دار مى باشندو

\begin{tabular}{|c|c|}
\hline ميانخين ويز گى هاى تحت بررسى & \\
\hline تعداد كلستريديوم ثرفرنجنس باقى مانده & وبع تيمارسو سيس \\
\hline$\Delta F Y . Y K Y \pm Y F A . F \cdot V^{C}$ & روز صفر \\
\hline $9.9 .99 \mathrm{~V} \pm 19 . \mathrm{V} 99^{\mathrm{BC}}$ & روز بـنجم \\
\hline $99 r . r r r \pm 9 \cdot . v 11^{B C}$ & ل روز دهم \\
\hline$V F q .19 V \pm q 1 . V 1 V^{A B}$ & روز يانزدهم \\
\hline$\Lambda 9 . \wedge r r \pm 119.9 v^{A}$ & 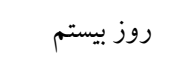 \\
\hline
\end{tabular}

آزمايشگاهى · ا نفر يانليست سوسيس هاى توليدى به همر اه نمونه شاهد مصرف نمودند. لازم به ذكر است كه امتيازات

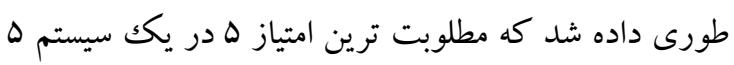
نقطه اى و بدترين امتياز ا را اخذ كرد.
نتايج جدول Y نشان مى دهد كه بين روزهاى مختلف نخهدارى از لحاظ كليه ويزگى هاى تحت بررسى اختلاف معنى دار در سطح ه درصد(ه . . > P (P) وجود دارد. براى بررسى خواص حسى انواع سوسيس هاى فرموله شده بااسانس ميوه درخت بنه و انطباق اين نتايج با نتايج

جدول r: مقايسه مجموع امتيازات داده شده خصوصيات حسى سوسيس هاى تحت تيمار

\begin{tabular}{|c|c|c|c|c|}
\hline \multicolumn{4}{|c|}{ مجموع امتيازات داده شده } & \multirow{2}{*}{ انواع سوسيس فرموله توليدى } \\
\hline برش بذيرى & طer & بو & رنگك & \\
\hline 19 & 11.8 & 19.0 & 19.0 & شاهد(نمونه رايج) \\
\hline if & 11.0 & irso & ir.s & حاوى اسانس بدون نيتريت \\
\hline
\end{tabular}

و نمونه سوسيس حاوى اسانس بدون نيتريت از نوع بدترين

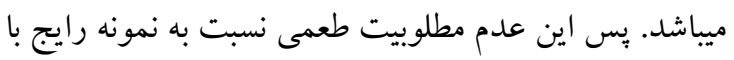

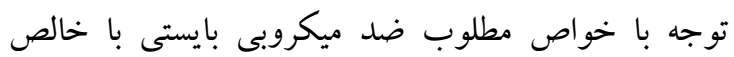
سازى و رنغك برى بر طرف گر دد.
نتايج موجود در جدول "انشان مى دهد كه بين نمونه هاى

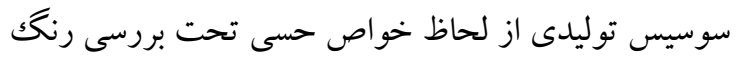
و بو و برش بذيرى داراى اختلاف معنى دار نمى باشد ولى لى لئل از لحاظ طعم كاملاًتفاوت معنى دار وجوددارد(ه .. (P)). نمونه سوسيس شاهد بهترين نمونه از لحاظ تمامى فاكتورها 
فرجى و همكاران در تحقيقى نشان دادند كه با افزايش

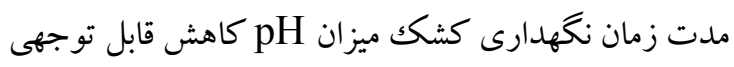
داشته است. همجنين جمعيت /ستافيلوكوكوس /ورئوس در مقايسه با كلستريديوم بوتولينوم با سرعت بيشترى از بين

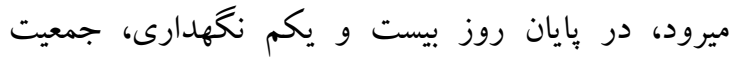
/ستافيلوكوكوس /ورئوس به صفر رسيده است. در نتيجه عصاره حاوى يكك درصد موسير هم به لحاظ كاهش رشد به ميكروبى و هم به لحاظ خصوصيات حسى و رنخك به عنوان مناسبترين نمونه انتخاب شد(IF). بر اساس نتايج حنفى و همكاران، فعاليت ضد ميكروبى،

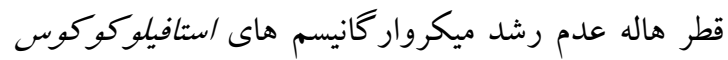

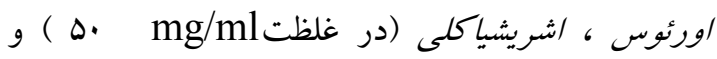

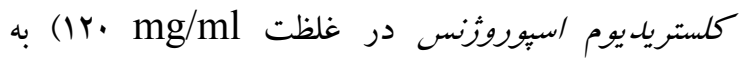

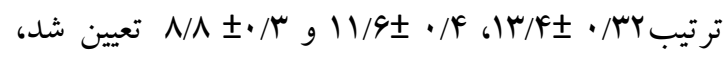
كه /ستافيلوكوكوس /ورئوس، بيشترين حساسيت و و كلستريديوم اسبوروثنس بيشترين مقاومت را به اسانس لهونس

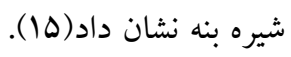
هميشه از گياهان و خواص درمانى آن ها براد هاى در مان مان

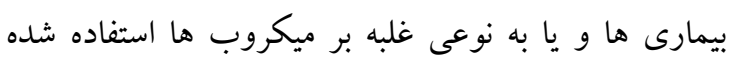

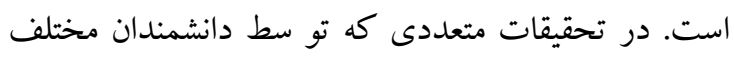

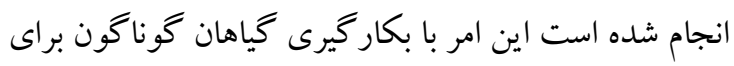

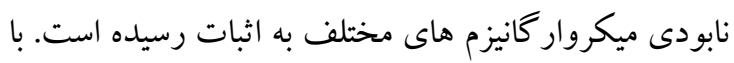

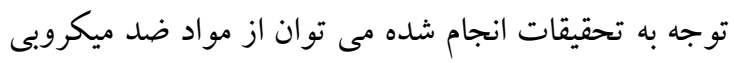

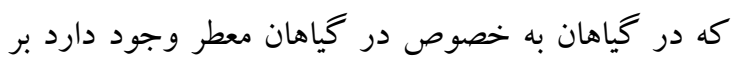

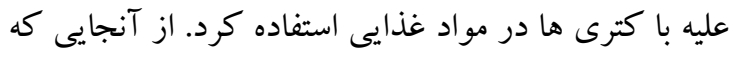

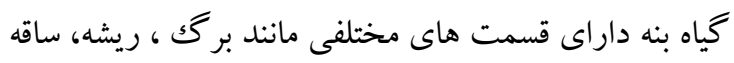

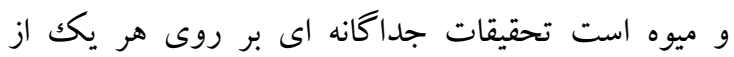
اجزاى و نيز خو اص ضد ميكروبى هر يكك از آنها انجام شده است. بر همين اساس در تحقيق ييش رو از اسانس ميوه بنه براى اثر بر روى كلستريديوم برفرنزنس استفاده شد كه كل

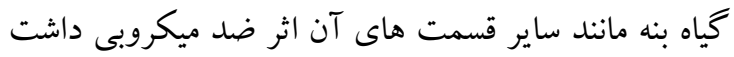
و باعث كنترل رشد ميكروب مورد نظر و ساير ميكروار كانيزم هاى باكتريايى شد. نتايج بدست آمده نشان مى دهد كه حداقل غلظت بازدارندكى اسانس بنه بر باكترى كلستريديوم يرفرنجنس

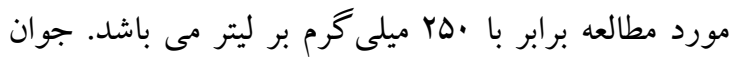
جبلى و همكاران (سوها) در تحقيق خود به اين نتيجه رسيدند حداقل غلظت بازدارندگى براى باكترىهاى گرمان

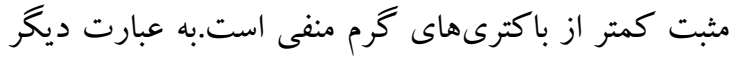

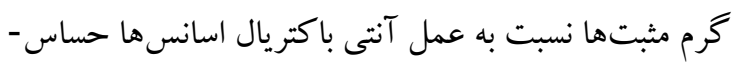
ترند. علت حساسيت كمتر گرم منفىها احتمالا به علت بر الت وجود غشا خارجى در باكترىهاى گرم منفى است كه سبب محدود شدن انتشار اجزا هيدروفوبيكك اسانس به لايه لييو

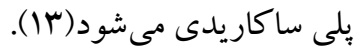
در مطالعه ديخـرى والكرو و همكارانش اثر

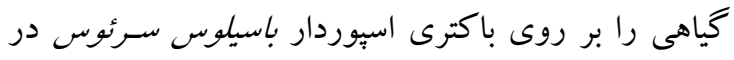

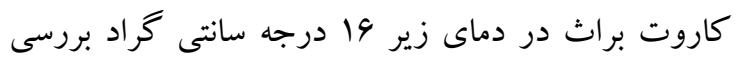

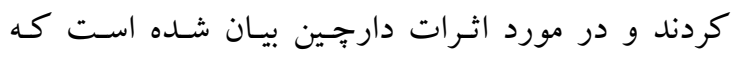
اضـافه كردن هـ ميكروليتراز اسانس براى هر صد ميلى ليتر

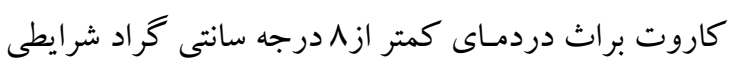

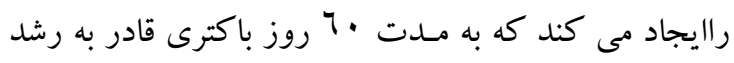

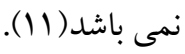
بررسى اثر اسانس هاى گياهى اين مواد بر روى ياتوزنهاى

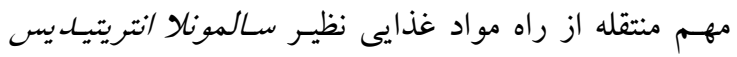
،شريشيا كلى ،كونه هاى شيخلا، باسـيلوس سـرئوس، استافيلوكوكوس اورئوس و ليستريا مونو سيتوثنز نشان

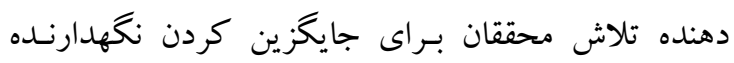

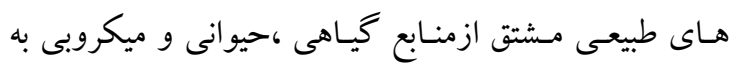

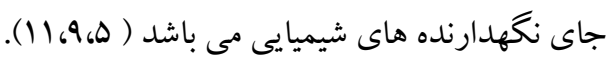

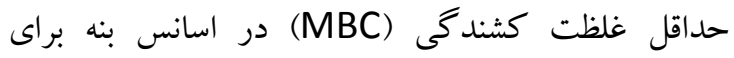
باكترى كلستريديوم برابر لمهات ميلى كرم در ليتر بود.

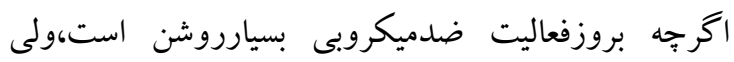
مكانيسم عملآ به طور كامل درك نشده است. 


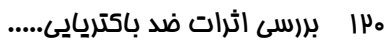

\section{نتيجه كيرى}

با توجه به نتايج حاصل از اين تحقيق اسانس بنه به عنوان

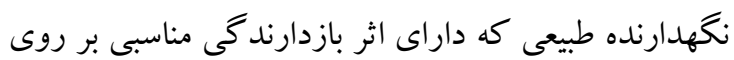

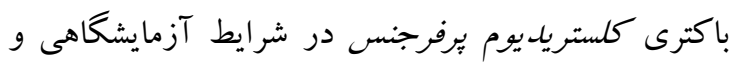

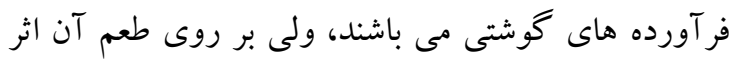

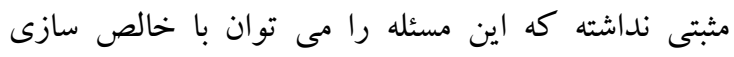
ورنگك برى حل كرد .اين نتايج نشان مىدهد كه اسانس ردانس

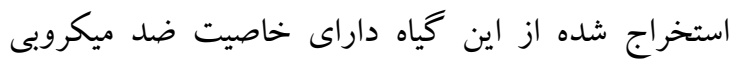
روى باكترى نامبرده بوده و توانايى استفاده به صورت

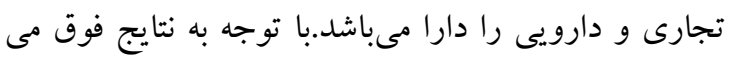

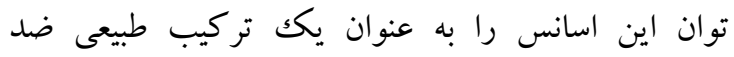
ميكروب در محصولات غذايى و دارويى استفاده نمود

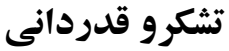

اين مقاله نتيجه بخشى از طرح تحقيقاتى مصوب مركز

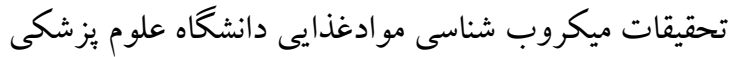
وخدمات بهداشتى درمانى تهران به شماره قرارداد MF9

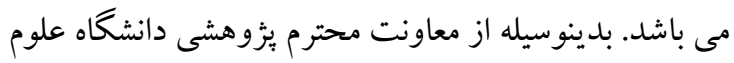
يز شكى تهران كه حامى مالى اين طرح تحقيقاتى مى باشند، كمال سباسگذارى وتشكر را داريم.
اين تحقيقات نشان داد اين اسانس مى توانند از رشد

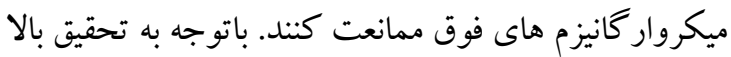
بى اثر بودن عصاره ابى در اين تحقيق تا حدودى قابل توجيه است كه عصاره آبى فاقد تركيبات موثر ضد باكترى

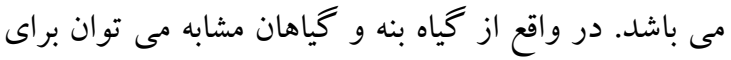

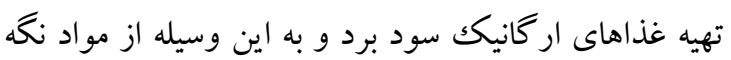
دارنده شيميايى و مواد آنتى باكتريال كه اثر سو بر سلامت

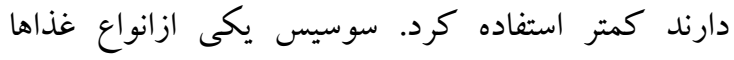
فر آوده هاى گوشتى هست كه اخر به جاى نيتريت از عصاره گياهان استفاده شود، مى تو انند به عنوان غذاهاى اركانيك هرك

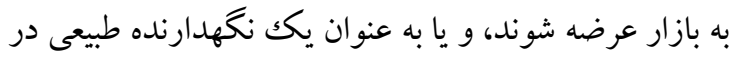

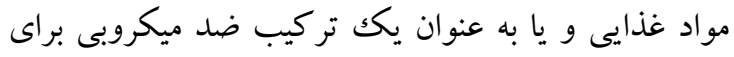
عفونت هاى ناشى از اين باكترى استفاده شود. در اين تحقيق ماده غذايى سوسيس بوده كه حاوى روغن اين وترى ادويه هاى مختلف بوده است و در واقع محيط مورد استفاده

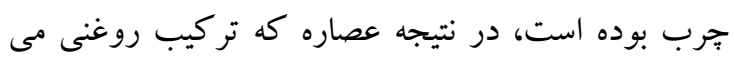

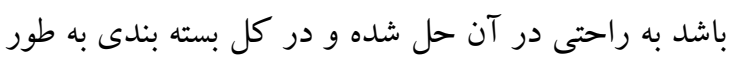

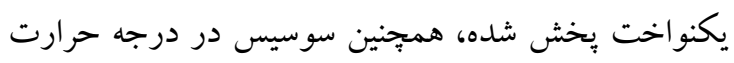
يخجال F درجه سانتيخر اد نكهدارى شد.

\section{References}

1. Hammer KA, Carson CF, Riley TV. Antimicrobial activity of essential oils and other plantextracts. J Appl Microbiol 1999; 86:985-90.

2. Gutierrez J, Barry-Ryan C, Bourke P. Antimicrobial activity of plant essential oils using food model media: Efficacy, synergistic potential and interactions with food components. Food Microbiol 2009;26:142-50.

3. Alvarez R, Encina A, Pe'rez Hidalgo N. PistaciaTerebinthus L. leaflets: an anatomical study. Plant Systematics and Evolution 2008;272:107-18.

4. Del Campo J, Amiot MJ, Nguyen C. Antibacterial effect of reosemary extracts. J Food Prot 2000;63:1359-68.

5. Ravanshad SH, Basiri E, Dastgheib B. Shirazi thyme essential oil concentration on antimicrobial activity of different bacteria, Enterococcus faecalis. Shiraz Univ Dent J 2007;8:28-36.

6. Amiri Aghdaei SF, Zareh Zardini H. Investigating the Factors Affecting the Improvement and Development of Medicinal Plants in Iran (Case Study: Esfehan City). J New Market Res 2012;1:195-214. 


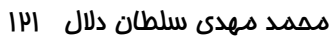

7. Ashayeri N, Abbassian AR, Janbakhsh S, Sheibani S, Sodagari F, Minaie MB. The more prevalent medicinal herbs which have been purchased from herbal medicine stores in Tehran, 2008. JIITM 2013; 3: 477-82. [In Persian]

8. Kout Soumanis K, Lambropoulon K, Nychas G JE. A predictive model for the nonthermal inactivation of Salmonella entritidis in a food model system supplemented with a natural antimicrobial. Int J Food Microbiol 1999;49:63-74.

9. Soltan Dallal M M, Bayat M, Yazdi M H, Aghaamiri S, Ghorbanzadeh Meshkani M, Abedi Mohtasab TP, et al. Antimicrobial effect of Zataria multiflora on antibiotic-resistant Staphylococcus aureus strains isolated from food. SJKU 2012; 17: 21-9. [In Persian]

10. Tassou C, Nychas GJE. Antimicrobial activity of essential oil of mastic gum (Pistacia lentiscus var. Chia) on gram positive and gram negative bacteria in broth and in model food system. Int Biodet Biodeg 1995;36:411-20.

11. Valero M, Salmeron MC. Antibacterial activity of 11 essential oils against Bacillus cereus in tyndallized carrot broth. Int J Food Microbiool 2003;85:73-81.

12. Serajoldini MF. Plant protection and medicine in ancient Iran. Medical History 2010; 2:11 33. [In Persian]

13. Javan Jebelli A, M, Hamedani Ahmadi A, Bayan M, Keykhosravy K, Abdollahi Z, Kanani M. Antioxidant and antimicrobial effect of different mints, the most widely used in Caspian sea areas, Iran. J Vet Res Lab 2014;6:93-102. [In Persian]

14. Farajii M, Roozbeh Nasiraie L, Farhoodi M. Antibacterial effect of ethanolic extract shallot (Allium Hirtifolium) on the Clostridium botulinum \& Staphylococcus aureus and orgoanoleptic propertise of liquid curd. Iranian J Nutri Sci Food Tech 2018;82:73-82. [In Persian]

15. Hanafi QM, Darvishi SH, Dervishi N, Sayedin Ardebili SM, Mirahamdi F. Antibacterial Properties of Embryonic Salt Essences on Staphylococcus aureus, Escherichia coli. SJKU 2011;17:1-11. [In Persian] 